\title{
Persistence of attenuated HIV-I rev alleles in an epidemiologically linked cohort of long-term survivors infected with nef-deleted virus Melissa J Churchill ${ }^{* 1}$, Lisa Chiavaroli ${ }^{1}$, Steven L Wesselingh ${ }^{1,2,3}$ and Paul R Gorry*1,2,3
}

Address: ${ }^{1}$ The Macfarlane Burnet Institute for Medical Research and Public Health, Melbourne, Victoria, Australia, ${ }^{2}$ Department of Microbiology and Immunology, University of Melbourne, Melbourne, Victoria, Australia and ${ }^{3}$ Department of Medicine, Monash University, Melbourne, Victoria, Australia

Email: Melissa J Churchill* - churchil@burnet.edu.au; Lisa Chiavaroli - lisa@burnet.edu.au; Steven L Wesselingh - stevew@burnet.edu.au; Paul R Gorry* - gorry@burnet.edu.au

* Corresponding authors

Published: I July 2007

Retrovirology 2007, 4:43 doi:10.1186/1742-4690-4-43

This article is available from: http://www.retrovirology.com/content/4/I/43

(c) 2007 Churchill et al; licensee BioMed Central Ltd.

This is an Open Access article distributed under the terms of the Creative Commons Attribution License (http://creativecommons.org/licenses/by/2.0), which permits unrestricted use, distribution, and reproduction in any medium, provided the original work is properly cited.

\begin{abstract}
Background: The Sydney blood bank cohort (SBBC) of long-term survivors consists of multiple individuals infected with nef-deleted, attenuated strains of human immunodeficiency virus type I (HIV-I). Although the cohort members have experienced differing clinical courses and now comprise slow progressors (SP) as well as long-term nonprogressors (LTNP), longitudinal analysis of nef/long-terminal repeat (LTR) sequences demonstrated convergent nef/LTR sequence evolution in SBBC SP and LTNP. Thus, the in vivo pathogenicity of attenuated HIV-I strains harboured by SBBC members is dictated by factors other than neflLTR. Therefore, to determine whether defects in other viral genes contribute to attenuation of these HIV-I strains, we characterized dominant HIV-I rev alleles that persisted in 4 SBBC subjects; Cl8, C64, C98 and D36.
\end{abstract}

Results: The ability of Rev derived from D36 and C64 to bind the Rev responsive element (RRE) in RNA binding assays was reduced by approximately $90 \%$ compared to Rev derived from HIV-I NL4- $_{\text {- }}$ 2, Cl8 or C98. D36 Rev also had a 50-60\% reduction in ability to express Rev-dependent reporter constructs in mammalian cells. In contrast, $\mathrm{C} 64 \mathrm{Rev}$ had only marginally decreased Rev function despite attenuated RRE binding. In D36 and C64, attenuated RRE binding was associated with rare amino acid changes at 3 highly conserved residues; Gln to Pro at position 74 immediately Nterminal to the Rev activation domain, and Val to Leu and Ser to Pro at positions I04 and I06 at the Rev C-terminus, respectively. In D36, reduced Rev function was mapped to an unusual 13 amino acid extension at the Rev C-terminus.

Conclusion: These findings provide new genetic and mechanistic insights important for Rev function, and suggest that Rev function, not Rev/RRE binding may be rate limiting for HIV-I replication. In addition, attenuated rev alleles may contribute to viral attenuation and long-term survival of HIV-I infection in a subset of SBBC members. 


\section{Background}

The Sydney blood bank cohort (SBBC) of long-term survivors (LTS) consists of multiple individuals who became infected with attenuated strains of human immunodeficiency type 1 (HIV-1) via contaminated blood products from a common blood donor between 1981 and 1984 [13]. Long-term prospective studies showed convergent evolution of nef/long-terminal repeat (LTR) sequences in virus harbored by SBBC members, characterized by progressive sequence deletions toward a minimal nef/LTR structure retaining only sequence elements required for viral replication [4]. Thus, gross deletions in the nef/LTR region of the HIV-1 genome contribute to viral attenuation and slow progression of HIV-1 infection in SBBC members. Despite convergent nef/LTR sequence evolution, after 22 to 26 years of infection SBBC members comprise antiretroviral therapy (ART)-naïve long-term nonprogressors (LTNP) as well as slow progressors (SP) who eventually commenced ART, suggesting that other viral and/or host factors may contribute to the in vivo pathogenicity (or lack thereof) of SBBC HIV-1 strains $[3,4]$.

Numerous viral and host factors have been shown to affect the rate of HIV-1 disease progression [reviewed in [5-7]]. Viral genetic factors other than nef/LTR associated with SP or LTNP include mutations in the HIV-1 gag, rev, $v i f, v p r, v p u$ and $e n v$ genes [8-13]. Host genetic factors linked to a delay in the onset of AIDS and prolonged survival include the CCR5 $\Delta 32$ mutation, CCR2-V64I polymorphism, and certain HLA haplotypes [14-17].

HIV-1 Rev is a 116 amino acid (aa), $18 \mathrm{kD}$ regulatory protein whose primary function is to mediate the nucleocytoplasmic transport, and therefore expression, of unspliced and singly spliced HIV-1 mRNA transcripts encoding viral structural proteins, via binding to the Rev response element (RRE) which is a complex RNA stemloop structure present in these transcripts [reviewed in [[18-21]]. Therefore, Rev activity is essential for HIV-1 replication. Extensive mutational analysis of Rev has identified 2 distinct functional domains [reviewed in [21]]. These include an arginine-rich $\mathrm{N}$-terminal region at aa positions 34 to 50 which contains the nuclear localization signal (NLS) and the RNA-binding domain (RBD) that mediates direct binding of Rev to the RRE, and a highly conserved leucine-rich C-terminal activation domain at aa positions 75 to 83 which contains the nuclear export signal (NES). The N-terminal NLS/RBD is flanked on both sides by less well defined sequences that are required for multimerization [22-25].

A previous study of rev alleles isolated from a subject with long-term nonprogressive HIV-1 infection showed a persistent Leu to Ile change at position 78 in the activation domain which attenuated Rev function and HIV-1 replication capacity [10], providing the first evidence that defective rev alleles may contribute to long-term survival of HIV-1 infection in some patients. A subsequent study of naturally occurring rev alleles with rare sequence variations in the activation domain showed variable reductions in Rev activity [26], although it was unclear from this study whether the reductions in Rev activity observed would be sufficient to attenuate HIV-1 replication capacity. In the present study, we undertook a genetic and functional analysis of HIV-1 rev alleles isolated from 4 SBBC subjects to determine whether defects in viral genes other than $n e f /$ LTR contribute to attenuation of HIV-1 strains harbored by SBBC members.

\section{Results and Discussion Subjects}

The clinical history of the study subjects, results of laboratory studies and antiretroviral therapies have been described in detail previously $[3,4,27]$. The results of laboratory studies relevant for the longitudinal samples used in this study are summarized in Table 1. Briefly, D36 acquired HIV-1 sexually in December 1980. C18, C64 and C98 acquired HIV-1 by receiving blood products donated by D36 in August 1983, April 1983 and February 1982, respectively. After 19 years of asymptomatic infection without ART, D36 was placed on highly active ART (HAART) in January 1999 after evidence of HIV-1 progression. C98 was also placed on HAART in November 1999 after 18 years of HIV-1 infection, and died of causes unrelated to HIV-1 in March 2001. C64 has been infected for 24 years without ART, and has stable CD4 T-cells and below detectable viral load. C18 died of causes unrelated to HIV-1 in November 1995, but prior to death was asymptomatic with stable CD4 T-cell count for 12 years without ART. Thus, D36 and C98 are SP, and C18 and C64 are LTNP $[3,4]$. CCR5 $\triangle 32$ genotyping by PCR showed that all subjects carried CCR5 (wt/wt) alleles ([28], and J. S. Sullivan, personal communication). CCR2-64I genotyping by PCR-RFLP showed that C64 and C98 carried the CCR2-64I (wt/wt) genotype [28]. The CCR2-64I genotype of C18 and D36 has not been determined.

\section{Persistence of unique rev alleles in SBBC members}

Peripheral blood mononuclear cells (PBMC) isolated from blood samples longitudinally collected on 4 occasions between 1995 and 2001 were available from D36, C64 and C98 for this study (Table 1). Only one blood sample collected in 1993 was available from C18. Blood was taken from subjects in accordance with guidelines endorsed by the Australian Red Cross Blood Service human ethics committee. Multiple, independent fulllength Rev clones containing the first and second Rev coding exons were generated from genomic DNA of each 
Table I: Subjects, longitudinal blood samples and corresponding laboratory studies.

\begin{tabular}{|c|c|c|c|c|c|c|}
\hline Subject & Date infected & $\begin{array}{l}\text { Date of blood } \\
\text { sample }\end{array}$ & $\begin{array}{l}\text { CD4+ T-cellsa } \\
(\text { cells } / \mu l)\end{array}$ & $\begin{array}{c}\text { Viral load b } \\
\text { (RNA copies/ } \\
\text { ml) }\end{array}$ & $\begin{array}{c}\text { HIV-I } \\
\text { progression } \\
\text { status }^{c}\end{array}$ & $\begin{array}{l}\text { No. Rev clones } \\
\text { sequenced }^{d}\end{array}$ \\
\hline \multirow[t]{4}{*}{ D36 } & $12 / 1980$ & $5 / 1995$ & N/A & 1400 & SP & 10 \\
\hline & & $1 / 1997$ & 367 & 3200 & & 10 \\
\hline & & $7 / 1999$ & $N / A$ & $\mathrm{BD}$ & & 10 \\
\hline & & $4 / 2001$ & 476 & BD & & 10 \\
\hline $\mathrm{Cl} 8$ & $8 / 1983$ & $12 / 1993$ & 809 & N/A & LTNP & 10 \\
\hline \multirow[t]{4}{*}{ C64 } & $4 / 1983$ & $8 / 1996$ & 925 & $\mathrm{BD}$ & LTNP & 10 \\
\hline & & $8 / 1997$ & 805 & $B D$ & & 10 \\
\hline & & $4 / 1999$ & 1026 & $B D$ & & 10 \\
\hline & & $5 / 2000$ & 875 & BD & & 10 \\
\hline \multirow[t]{4}{*}{ C98 } & $2 / 1982$ & $10 / 1995$ & 576 & 670 & SP & 10 \\
\hline & & $2 / 1997$ & 629 & 770 & & 10 \\
\hline & & $11 / 1999$ & 646 & 690 & & 10 \\
\hline & & $5 / 2001$ & 527 & 760 & & 10 \\
\hline
\end{tabular}

a; CD4+ T-cells were measured by flow cytometry.

b; Plasma HIV-I RNA was measured by COBAS Amplicor HIV-I Monitor Version I.0 (Roche Molecular Diagnostic Systems, Branchburg, N.J.) prior to July 1999 and Version I.5 after July 1999. HIV-I RNA levels $<400$ copies/ml (Version I) or < 50 copies/ml (Version I.5) were considered below detection.

c; The clinical status of the subjects has been described in detail previously [3, 4, 27].

$\mathrm{d}$; The consensus sequences of the $10 \mathrm{Rev}$ clones sequenced from each time point are shown in Additional file I.

$\mathrm{BD}$, below detection; N/A, not available; SP, slow progressor; LTNP, long-term nonprogressor.

PBMC sample and sequenced. Phylogenetic analysis showed that all Rev sequences were clade B (data not shown). The dominant Rev aa sequence from each PBMC sample, which represents the consensus sequence from 10 independent clones, is shown in Additional file 1. In each subject where longitudinal PBMC samples were available (D36, C64 and C98), the persistence of a dominant rev allele was evident over a 4- to 6-year period. Figure 1 shows an aa sequence alignment of these dominant and persistent $r e v$ alleles as well as the dominant rev allele in the single C18 PBMC sample. Single aa changes at positions 74, 104, 106, 108 and 112 in sequence encoding Rev exon 2 segregated the dominant C18 and C98 Revs from the dominant C64 and D36 Revs. However, each dominant Rev sequence contained unique, distinguishing aa changes. In addition, C18, C64 and C98 Revs had a 3 aa extension at the Rev C-terminus, and D36 Revs had a 13 aa extension at this position. Similar C-terminal extensions were not identified in $164 \mathrm{Rev}$ sequences available in the Los Alamos data base and other published studies [10]. Thus, the dominant and persistent Revs harbored by these SBBC members are unique. The following studies functionally characterized Rev proteins derived from these dominant and persistent SBBC rev alleles.

\section{Rev proteins derived from subjects C64 and D36 have attenuated RRE binding capacity}

The ability of His-tagged Rev proteins derived from the dominant and persistent SBBC rev alleles to bind the RRE was quantified by electrophoretic mobility shift assays with [ $\left.{ }^{32} \mathrm{P}\right]$-labelled RNA transcripts bearing the RRE (Fig. 2A). His-tagged Rev and Matrix proteins derived from HIV-1 $1_{\text {NL4-3 }}$ were used as positive and negative controls, respectively. Compared to His-tagged Rev from HIV- $1_{\text {NL4- }}$ ${ }_{3}$, the ability of His-tagged Revs from D36 and C64 to form Rev/RRE complexes at non-saturating Rev concentrations $(0.25 \mu \mathrm{M})$ was reduced by approximately $90 \%$ (Fig. 2B). In contrast, the ability of His-tagged Revs from C18 and C98 to form Rev/RRE complexes at non-saturating Rev concentrations was similar to His-tagged Rev from HIV-1 $1_{\mathrm{NL} 4-3}$. These results indicate that Rev proteins derived from the dominant and persistent D36 and C64 rev alleles have attenuated ability to bind the RRE.

\section{Rev amino acid sequences associated with attenuated RRE binding}

Attenuated RRE binding was not due to mutations in the $\mathrm{N}$-terminal $\mathrm{RBD}$, since the amino acid sequences across this region were conserved among all SBBC rev alleles and were identical to HIV-1 $1_{\mathrm{NL4}-3}$ (Fig. 1). This was somewhat surprising, since previous studies showed that the RBD of Rev was the principal determinant of RRE binding [2325,29-32]. The C-terminal 3 aa extensions present in C18, 


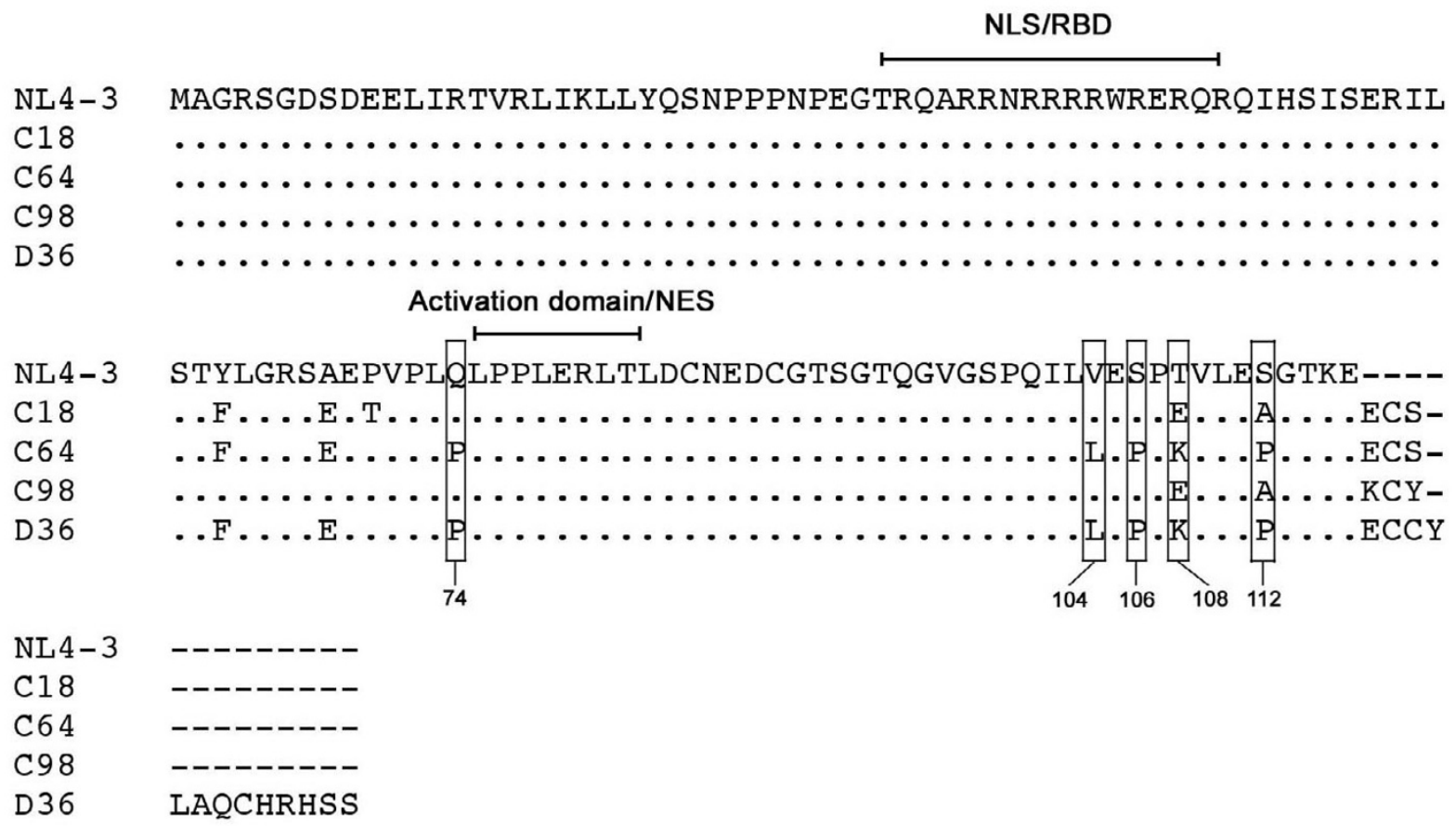

\section{Figure I}

Amino acid sequences of persistent and dominant SBBC rev alleles. The HIV-I Rev amino acid sequences shown represent those derived from the dominant and persistent rev alleles harboured by SBBC subjects C18, C64, C98 and D36. They are the consensus sequences of multiple independent Rev clones that persisted over a 4- to 6-year period in C64, C98 and D36, or which were dominant in a single blood sample obtained from Cl8 [see Additional file I]. Amino acid alignments are compared to Rev from HIV-I $\mathrm{NL4-3}_{\text {. }}$. Dots indicate residues identical to HIV-I $\mathrm{NL4-3} \mathrm{Rev}$, and dashes indicate gaps. Boxed residues indicate amino acid substitutions which discriminate CI8 and C98 Revs from C64 and D36 Revs. NLS; nuclear localization signal, RBD; RNA binding domain, NES; nuclear export signal.

C64 and C98 Revs (Fig. 1) had no effect on RRE binding, since RRE binding by $\mathrm{C} 18$ and $\mathrm{C} 98$ Revs was similar to HIV-1 $1_{\text {NL4-3. }}$. Three amino acid changes that were conserved among D36 and C64 rev alleles and that were not present in $\mathrm{C} 18$ and $\mathrm{C} 98$ rev alleles were identified outside the RBD; Gln to Pro at position 74 immediately N-terminal to the Rev activation domain, and Val to Leu and Ser to Pro at positions 104 and 106 at the Rev C-terminus, respectively (Fig. 1). Amino acid changes also occurred at positions 108 and 112 which segregated C64 and D36 Revs from C18 and C98 Revs, but database analysis showed that amino acid variation is frequent at these positions (data not shown). Thus, amino acid changes at positions 108 and 112 are not likely to affect Rev/RRE binding. In contrast, the clade B consensus residues Gln-74, Val-104 and Ser-106 are normally highly conserved, with residue frequencies of 0.90, 0.94 and 0.97, respectively (Table 2). Pro-74, Leu-104 and Pro-106 are rare amino acid changes among clade B Revs; Only 16 rev alleles from 164 sequences available in the Los Alamos data base and other published studies [10] had Pro-74, Leu-104 or Pro-106, with individual residue frequencies of $0.049,0.018$ and 0.018 , respectively (Table 2). The frequency of any 2 of these residues being present was 0.006. None of the available sequences had all 3 amino acid changes. Thus, the amino acid changes occurring in D36 and C64 Revs are unique. However, the presence of one or more of these amino acid changes was not able to discriminate between subjects with progressive or non-progressive HIV-1 infection (Table 2). Moreover, none of these amino acid changes occurred in a previously identified LTNP with defective rev alleles [patient MA [10], Table 2]. Thus, the contribution of any or all of these mutations to decreased RRE binding by D36 and C64 Revs, and possibly to slow or absent HIV-1 progression, is likely to be context dependent. Further mutagenesis studies are required to determine the contribution of Pro-74, Leu-104 or Pro-106 to diminished RRE binding by these Rev variants.

Rev is a highly structured protein [reviewed in $[20,21]]$. Biochemical and structural studies identified an $\alpha$-helix at aa 8 to 26, and another at aa 34 to 59 spanning the NLS/ 

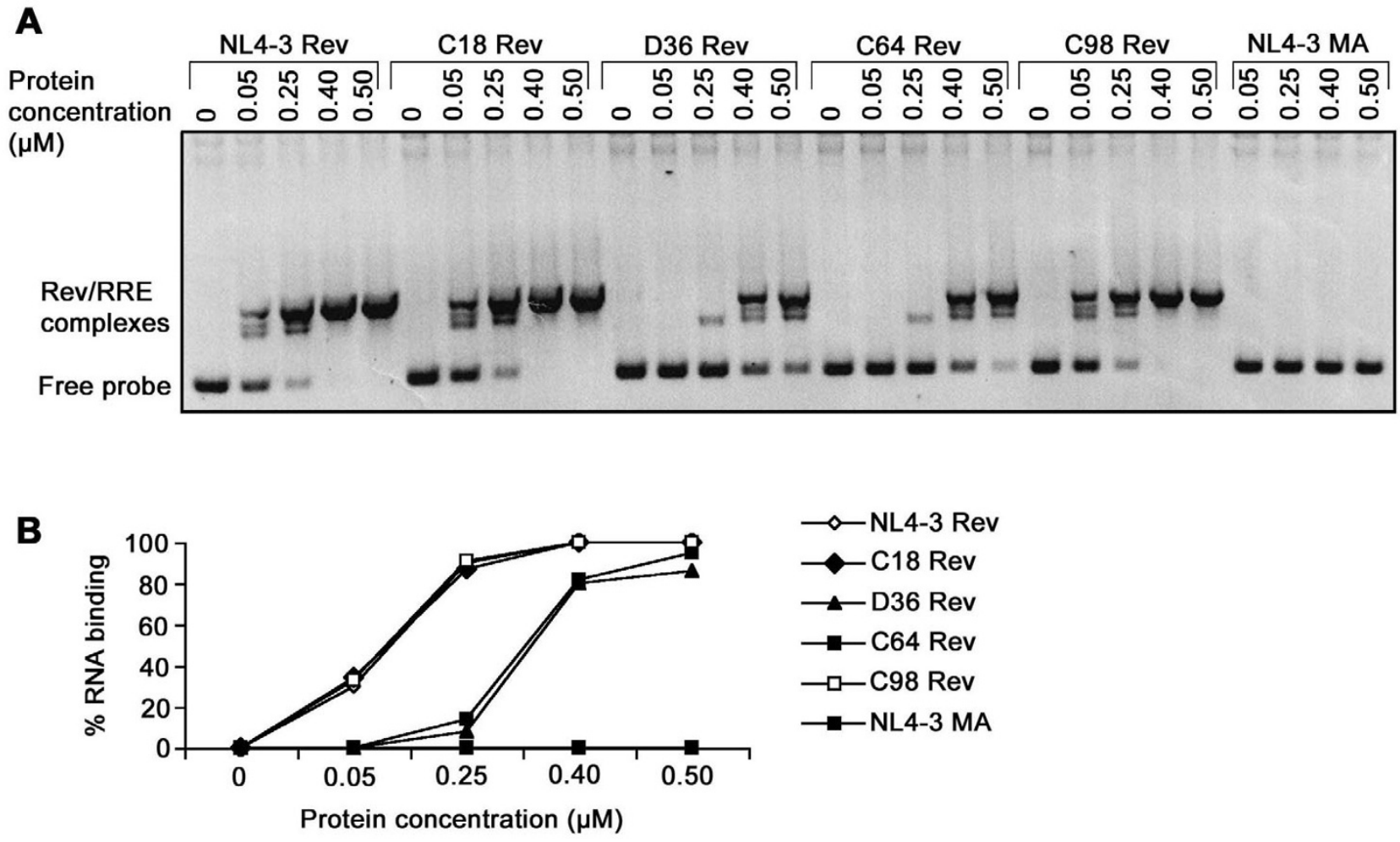

Figure 2

Analysis of Rev/RRE binding. RNA binding assays were conducted with [ $\left.{ }^{32} \mathrm{P}\right]$-labelled RRE riboprobes and increasing concentrations of His-tagged Rev proteins, as described in Materials and Methods. Binding reactions containing increasing concen-

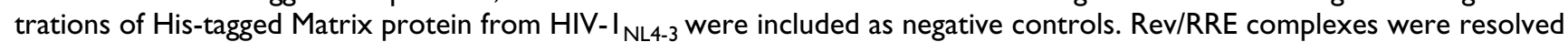
by electrophoresis in $5 \%$ (wt/vol) native polyacrylamide gels and visualized by autoradiography $(A)$. Bands were quantified by phosphorimager analysis, and the percentage of RNA binding was calculated by dividing the signal intensity of bands associated with Rev/RRE complexes by the signal intensity of all bands, and multiplying this number by 100 (B). The data shown are representative of three independent experiments. ${ }^{*} p<0.0$ I, Student's $t$ test.

RBD, separated by a Pro-rich region at aa 27 to 39, which folds into a helix-loop-helix structure where intramolecular contacts between the $2 \alpha$-helices are facilitated by hydrophobic interactions [reviewed in [20]]. The Rev RBD within the latter $\alpha$-helix interacts specifically with an internal loop of the RRE through major groove interactions [33]. The C-terminal region of Rev is thought to be more flexible. However, a discontinuous epitope of a Revspecific monoclonal antibody was mapped to aa 10 to 20 and 95 to 105 by protein foot printing, suggesting that the $\alpha$-helices are in close proximity to the Rev C-terminus $[34,35]$, and suggesting a role for the C-terminus in stabilizing native Rev structure. Thus, aa changes occurring at the Rev C-terminus or elsewhere such as Pro-74, Leu-104 and/or Pro-106 could potentially affect Rev structure and thus, Rev/RRE binding. Proline provides exceptional conformational rigidity to proteins. Thus, It is possible that Pro-74 and/or Pro-106 may impede RRE binding by altering native Rev structure.
Rev derived from D36, but not C64, has impaired function To determine whether SBBC Revs have impaired function, D36, C64, C18 and C98 Revs were subcloned into the pcDNA3.1 expression vector. Western blot analysis of Rev protein expression using sheep polyclonal anti-Rev antiserum showed equivalent levels of Rev in lysates of transfected CEM cells (Fig. 3A). Rev function in mammalian cells was investigated using the Rev-dependent reporter plasmid pDM128 [31], which expresses the chloramphenicol acetyltransferase (CAT) gene in the presence of Rev, as described previously [36] (Fig. 3B). In this assay, the Rev expression plasmids were first titrated to determine an amount to use that was within the linear response range of the assay (data not shown). Levels of CAT activity were compared to those present in lysates of cells co-transfected with pDM128 and HIV- $1_{\mathrm{NL} 4-3}$ Rev. Cells cotransfected with pDM128 and empty pcDNA3.1 vector or pcDNA3. 1 expressing $\mathrm{HIV}-1_{\mathrm{NL} 4-3}$ Matrix protein were included as negative controls. Levels of CAT activity 
Table 2: rev alleles with rare Pro-74, Leu-104 and/or Pro-106 mutations ${ }^{\mathrm{a}}$

\begin{tabular}{|c|c|c|c|c|c|c|c|}
\hline \multirow{2}{*}{$\begin{array}{l}\text { Clade B HIV-I } \\
\text { strain or Rev } \\
\text { clone }\end{array}$} & \multicolumn{3}{|c|}{$\begin{array}{l}\text { Residue at position: (Clade B consensus residue; } \\
\left.\text { frequency }{ }^{b}\right)\end{array}$} & \multirow{2}{*}{$\begin{array}{l}\text { Frequency of } \\
\text { residue } \\
\text { combination }^{\mathrm{b}}\end{array}$} & \multirow[t]{2}{*}{$\begin{array}{l}\text { Status of HIV-I } \\
\text { progression }^{d}\end{array}$} & \multirow[t]{2}{*}{$\begin{array}{l}\text { GenBank } \\
\text { accession no. }\end{array}$} & \multirow[t]{2}{*}{ Reference } \\
\hline & 74 (GIn; 0.90) & 104 (Val; 0.94) & 106 (Ser; 0.97) & & & & \\
\hline C64 & Pro & Leu & Pro & unique & LTNP & EF634I55 & This report \\
\hline D36 & Pro & Leu & Pro & unique & LTS & EF634I54 & This report \\
\hline$M A^{c}$ & Gln & Val & Ser & 0.884 & LTS & N/A & Iversen et al., [10] \\
\hline C42 & Pro & Val & Ser & 0.049 & $N / A$ & AF538305 & Unpublished \\
\hline D3I & Pro & Val & Ser & 0.049 & N/A & $\mathrm{U} 43096$ & Kreutz et al., [48] \\
\hline UKRI216 & Pro & Val & Ser & 0.049 & $N / A$ & AFI93278 & Liitsola et al., [49] \\
\hline NY5CG & Gln & Leu & Ser & 0.018 & AIDS & M38431 & Willey et al., [50] \\
\hline 89.6 & Pro & Val & Ser & 0.049 & AIDS & U39362 & Collman et al., [5I] \\
\hline WEAUI60 & Pro & Leu & Ser & 0.006 & $N / A$ & $\underline{U 21135}$ & Unpublished \\
\hline 1299_d22 & $\mathrm{His}$ & $\overline{\mathrm{Val}}$ & Pro & 0.018 & $N / A$ & AY30876I & $\begin{array}{c}\text { Bernardin et al., } \\
{[52]}\end{array}$ \\
\hline 1006_08 & Pro & Val & Ser & 0.049 & Acute infection & $\mathrm{AY} 331284$ & $\begin{array}{c}\text { Bernardin et al., } \\
{[53]}\end{array}$ \\
\hline 1058_08 & Pro & Val & Ser & 0.049 & Acute infection & AY331294 & $\begin{array}{c}\text { Bernardin et al., } \\
{[53]}\end{array}$ \\
\hline PRB959_03 & Gln & Val & Pro & 0.018 & Acute infection & AY331296 & $\begin{array}{c}\text { Bernardin et al., } \\
{[53]}\end{array}$ \\
\hline RUI28005 & Gln & Val & Pro & 0.018 & $N / A$ & AY682547 & Unpublished \\
\hline $\begin{array}{l}98 \text { USHVTN3605c } \\
9\end{array}$ & Pro & Val & Ser & 0.049 & $N / A$ & AY560108 & Unpublished \\
\hline PCMOI3 & Glu & Leu & Ser & 0.018 & N/A & AY561237 & Unpublished \\
\hline $50333-03$ & Gln & Leu & Ser & 0.018 & LTS & $\underline{\text { U30750 }}$ & Iversen et al., [10] \\
\hline $931395-04$ & Pro & Val & Ser & 0.049 & AIDS & $\underline{\text { U30775 }}$ & Iversen et al., [10] \\
\hline LA-09 & Gln & Leu & Pro & 0.006 & AIDS & $\underline{\text { U30785 }}$ & Iversen et al., [10] \\
\hline
\end{tabular}

a; Sixteen of I64 Clade B HIV-I rev sequences screened from the Los Alamos National Laboratory HIV Database and other published studies [I0] contained Pro-74, Leu- I04 and/or Pro- 106 mutations. Underlined boldface indicates the presence of one or more of these rare amino acid changes.

b; Amino acid frequency was calculated by dividing the number of sequences with the amino acid, or the particular amino acid combination, by the total number of sequences analyzed $(n=164)$

c; Patient MA, identified as a LTS with attenuated rev alleles in a previous study by lversen et al., [10] was included for comparison.

d; LTNP, long-term nonprogressor; LTS, long-term survivor; AIDS, acquired immune deficiency syndrome; N/A, not available.

in lysates of cells transfected with C18 or C98 Revs were not significantly different to those in lysates of cells transfected with HIV- $1_{\mathrm{NL} 4-3}$ Rev. In contrast, levels of CAT activity in lysates of cells transfected with C64 or D36 Revs were reduced by approximately $20 \%$ and $50 \%$, respectively $(P<0.01)$. Similar results were obtained using 293 cells (data not shown). In addition, similar results were obtained using a Rev-dependent HIV-1 env reporter system as a measure of Rev function, as described previously [37] (data not shown). These data suggest efficient Rev function by $\mathrm{C} 18$ and C98 Revs, a modest reduction in the activity of C64 Rev, but significant impairment in the activity of D36 Rev.

\section{Amino acid sequences associated with impaired D36 Rev function}

Efficient C18 and C98 Rev function is consistent with results of the Rev/RRE binding studies that showed efficient RRE binding by these Revs (Fig. 2). However, the modest or significant impairment in C64 or D36 Rev activity, respectively, is discrepant with results of the Rev/ RRE binding studies that showed equivalent reductions in RRE binding by these Rev variants (Fig. 2). Therefore, in C64 Rev, the reduced levels of RRE binding appear to be sufficient for the majority of Rev function to be retained.
Additional sequence changes that differentiate C64 and D36 Revs are likely to impair D36 Rev function. Longitudinal sequence analysis showed that the presence of an unusual 13 aa extension at the D36 Rev C-terminus was the only genetic alteration that consistently differentiated D36 Rev from C64 Rev (Fig. 1), [see also Additional file 1]. The otherwise isogenicity of the D36 and C64 Revs used in the functional studies identifies the C-terminal 13 aa extension as the primary determinant underlying impaired D36 Rev function.

It is presently unclear how this sequence alteration may affect D36 Rev function, but the additional 13 aa at the Rev C-terminus may affect Rev structure. One hypothesis is that such structural changes may interfere with the recruitment of cellular proteins to the NES such as eIF-5A [38], nucleoporins including Rip/Rab [39-43] and CRM1/ exportin 1 [44-46], which could potentially affect nuclear export. The presence of Pro at position 74 immediately Nterminal to the Rev NES may induce further structural changes contributing to this interference, which might also account for the modest reduction in C64 Rev activity. Further studies are required to fully elucidate the importance of amino acid alterations that impair D36 Rev function. 
A
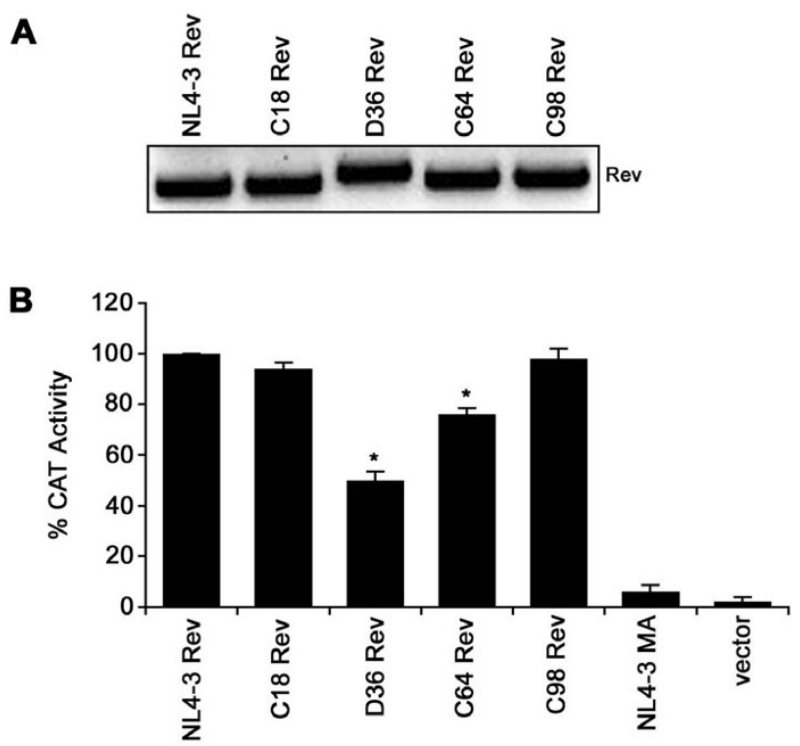

Figure 3

Analysis of Rev protein expression and function in mammalian cells. Rev function was examined by co-transfection of CEM cells with pcDNA3.I-Rev plasmid and the Rev-dependent pDMI28 CAT expression plasmid [3I], as described in Materials and Methods. Cells co-transfected with pDMI 28 and pcDNA3.I expressing HIV-I ${ }_{\text {NL4-3 }}$ Matrix protein or empty pcDNA3.I vector were included as negative controls. Rev protein expression was determined by Western blotting with sheep anti-Rev polyclonal antisera $(A)$. CAT activity in cell lysates was quantified and normalized to CAT activity in lysates of CEM cells co-transfected with PDMI 28 and NL4-3 Rev (B). Values shown are means of triplicate transfections. Error bars represent standard deviations. Results are representative of three independent experiments. $* P<0.01$, Student's $t$ test.

\section{Conclusion}

In this study, we demonstrate reduced capacity of persistent and dominant Rev variants isolated from a subset of SBBC members to bind the RRE, which was associated with unique rev alleles carrying rare amino acid substitutions at 3 highly conserved positions outside the RBD; Gln to Pro at position 74 immediately N-terminal to the Rev activation domain, and Val to Leu and Ser to Pro at positions 104 and 106 at the Rev C-terminus, respectively. However, decreases in Rev/RRE binding per se were not sufficient to attenuate Rev function. This conclusion is supported by studies of C64 Rev, which had significantly reduced RRE binding but only modestly reduced Rev function. Additional sequence changes present in D36 Rev attenuated Rev function. This was mapped to an unusual 13 aa extension at the Rev C-terminus, which was the only genetic change that distinguished C64 and D36 rev alleles. This genetic alteration may alter structural properties of Rev that are required for optimal Rev function. Together, our data suggest that Rev function, not Rev/RRE binding may be rate limiting for HIV-1 replication.

It is presently unclear whether attenuated D36 Rev function in vitro equates to attenuated Rev function in vivo, and indeed whether attenuated Rev function contributed to slow progression of HIV-1 infection in this subject. Extrapolation of these in vitro findings to an in vivo role for attenuated D36 rev alleles is difficult, since this subject and other SBBC members are infected with virus containing gross nef/LTR deletions which have been shown to contribute significantly to viral attenuation in this cohort $[1,4,27]$. Furthermore, the attenuated properties of D36 and C64 Revs did not distinguish SBBC LTNP from SP. In fact, among the SBBC subjects studied here, D36 had the most attenuated rev alleles yet the most progressive HIV-1 infection, suggesting that any effect that attenuated rev alleles may have in vivo is likely to be dependent on other viral and/or host factors. Nonetheless, our results support those of a previous study that showed attenuated Rev function in an asymptomatic individual [10], and those of another study that showed reduced Rev function among rev alleles with naturally occurring sequence variations [26], raising the possibility that attenuated Rev function may contribute, at least in part, to viral attenuation and slow HIV-1 progression in D36. However, in contrast to these studies where attenuated Rev function was mapped to mutations in the activation domain $[10,26]$, attenuated Rev function in D36 was mapped to the Rev C-terminus.

In sum, these findings provide new genetic and mechanistic insights important for Rev function. In addition, attenuated rev alleles may contribute to viral attenuation and long-term survival of HIV-1 infection in a subset of SBBC members. A better understanding of viral determinants other than nef/LTR that contribute to HIV-1 pathogenicity (or lack thereof) in SBBC members may provide additional mechanistic insights important for controlling HIV1 infection in vivo.

\section{Methods}

\section{Rev cloning and sequencing}

Full-length HIV-1 Rev clones containing the first and second Rev coding exons were generated from genomic DNA of patient PBMC samples by PCR using Expand high fidelity DNA polymerase (Roche Diagnostics, Basel, Switzerland) as follows; The first Rev coding exon was amplified using primers 5RevE2 (5'-GGGTGTCGACATAGCAGAATAG-3'; corresponding to nt positions 5781 to 5802 of $\left.\mathrm{HIV}-1_{\mathrm{NL} 4-3}\right)$ and 3RevE2 (5'-CTGCTTTGATAGAGAAGCTTG-3'; corresponding to nt positions 6024 to 6044 of HIV-1 $1_{\text {NL4-3 }}$ ) that spans a Sall restriction site 5 ' to the Rev start codon. The second Rev coding exon was 
amplified using primers 5RevE3 (5'-CCACCTCCCAATCCCGAGGGG-3'; corresponding to nt positions 8371 to 8391 of HIV-1 $1_{\text {NL4-3 }}$ ) and 3 RevE3 (5'-CTAGGTCTCGAGATACTGCTC-3'; corresponding to nt positions 8879 to 8898 of $\left.\mathrm{HIV}-1_{\mathrm{NL} 4-3}\right)$ that spans an XhoI restriction site 3 ' to the Rev stop codon. To avoid sequence resampling, six independent PCRs of Rev exon 1 or Rev exon 2 coding sequence were pooled prior to 3-way ligation in pGEM (Promega, Madison, WI) using SalI and XhoI restriction sites and blunt end ligation to link the Rev exon 1 and Rev exon 2 coding sequences.

Ten independent Revs cloned from each PBMC sample were sequenced using a SequiTherm EXCEL II DNA sequencing kit (Epicenter Technologies, Madison, WI) and model 4000L LI-COR DNA sequencer (LI-COR, Lincoln, NE). Predicted aa sequences were deduced from nucleotide sequences, and aligned and analyzed using DNAMAN software (Lynnon, Quebec, Canada).

\section{Rev/RRE binding assays}

His-tagged Rev proteins derived from SBBC rev alleles were produced, purified and quantified using the pET bacterial expression system (Novagen, Madison, WI), according to the manufacturers' protocol. The ability of Histagged Rev proteins to bind the RRE was quantified by electrophoretic mobility shift assays with [ $\left.{ }^{32} \mathrm{P}\right]$-labelled RNA transcripts bearing the RRE, as described previously [47]. Briefly, binding reactions consisted of excess [ $\left.{ }^{32} \mathrm{P}\right]-$ labelled RNA and increasing concentrations of His-tagged Rev protein $(0,0.05,0.25,0.40$ or $0.50 \mu \mathrm{M})$ in $10 \mu \mathrm{l}$ binding buffer [10 mM HEPES/KOH (pH 7.6), $150 \mathrm{mM} \mathrm{KCl,} 2$ $\mathrm{mM} \mathrm{MgCl} 2,0.5 \mathrm{mM}$ EGTA, $1 \mathrm{mM}$ dithiothreitol, 20\% (vol/vol) glycerol, $3.2 \mu \mathrm{g} \mathrm{E}$. coli tRNA]. Reactions were incubated on ice for $10 \mathrm{~min}$, then applied to $5 \%$ (wt/vol) nondenaturing polyacrylamide gels containing $100 \mathrm{mM}$ Tris borate (pH 8.3), 1 mM EDTA, and 3\% (vol/vol) glycerol and run at $4{ }^{\circ} \mathrm{C}$ followed by autoradiography and phosphorimager analysis.

\section{Rev function assays}

To facilitate Rev protein expression in mammalian cells, SBBC rev alleles were subcloned into the pcDNA3.1 expression vector (Invitrogen, Carlsbad, CA). Rev function in mammalian cells was quantified using the Revdependent reporter plasmid pDM128, which expresses the CAT gene from an intron bearing the RRE in the presence of HIV-1 Rev [31]. Briefly, CEM cells were cotransfected with $4.0 \mu \mathrm{g}$ pDM128, $0.75 \mu \mathrm{g}$ pcDNA.1-Rev plasmid and $0.25 \mu \mathrm{g}$ pEGFP plasmid to control for transfection efficiency. The Rev expression plasmids were titrated first to determine an amount to use that was within the linear response range of the assay (data not shown). After minor volume adjustments for small variations in transfection efficiency, cell lysates were prepared at $72 \mathrm{~h}$ post-transfection and assayed for CAT activity as described previously [36].

\section{Western blot analysis}

Lysates were prepared from CEM cells that were transfected as described above, separated in 12\% (wt/vol) SDSpolyacrylamide gels, and transferred to nitrocellulose membranes, as described previously [37]. Blots were probed with a 1:500 dilution of sheep anti-Rev polyclonal antisera (ICN). Rev proteins were visualized using horseradish peroxidase-conjugated anti-sheep immunoglobulin G antibody and enhanced chemiluminescence (Promega).

\section{Nucleotide accession numbers}

The rev nucleotide sequences reported here have been assigned GenBank accession numbers EF634153 to EF634156.

\section{Competing interests}

The author(s) declare that they have no competing interests.

\section{Authors' contributions}

MJC and PRG designed the study, MJC and LC performed the experiments, MJC and PRG analyzed the data and wrote the paper, SLW contributed to the experimental design and data analysis.

\section{Additional material}

\section{Additional file 1}

Consensus Rev amino acid sequences from sequential SBBC blood samples. Each sequence represents the consensus of 10 independent Rev clones from each time point. Amino acid alignments are compared to Rev from $H I V-1_{N L 4-3}$. Dots indicate residues identical to HIV-1 ${ }_{N L 4-3}$ Rev, and dashes indicate gaps. Note the persistence of a dominant rev allele in each subject over the time course studied.

Click here for file

[http://www.biomedcentral.com/content/supplementary/17424690-4-43-S1.jpeg]

\section{Acknowledgements}

We thank J. Learmont and J. Sullivan for providing patient blood samples. M.J.C. was supported by a grant from the Australian National Center for HIV Virology Research. P.R.G was supported, in part, by grants from the Australian National Health and Medical Research Council (NHMRC) (25I520) and NIH/NIAID (AI054207-0I). P.R.G. is the recipient of an NHMRC R. Douglas Wright Biomedical Career Development Award.

\section{References}

I. Deacon NJ, Tsykin A, Solomon A, Smith K, Ludford-Menting $M$, Hooker DJ, McPhee DA, Greenway AL, Ellett A, Chatfield C, Lawson VA, Crowe S, Maertz S, Sonza S, Learmont J, Sullivan JS, Cunningham A, Dwyer D, Dowton D, Mills J: Genomic structure of an atten- 
uated quasi species of HIV-I from a blood transfusion donor and recipients. Science 1995, 270(5238):988-99I.

2. Learmont J, Tindall B, Evans L, Cunningham A, Cunningham P, Wells J, Penny R, Kaldor J, Cooper DA: Long-term symptomless HIV$\mathrm{I}$ infection in recipients of blood products from a single donor. Lancet 1992, 340(8824):863-867.

3. Learmont JC, Geczy AF, Mills J, Ashton LJ, Raynes-Greenow CH, Garsia RJ, Dyer WB, McIntyre L, Oelrichs RB, Rhodes DI, Deacon NJ, Sullivan JS: Immunologic and virologic status after I 4 to $I 8$ years of infection with an attenuated strain of HIV-I. A report from the Sydney Blood Bank Cohort. N Engl J Med 1999, 340(22): $1715-1722$

4. Churchill MJ, Rhodes DI, Learmont JC, Sullivan JS, Wesselingh SL, Cooke IR, Deacon NJ, Gorry PR: Longitudinal analysis of human immunodeficiency virus type I nef/long terminal repeat sequences in a cohort of long-term survivors infected from a single source. / Virol 2006, 80(2): 1047-1052.

5. O'Brien SJ, Moore JP: The effect of genetic variation in chemokines and their receptors on HIV transmission and progression to AIDS. Immunol Rev 2000, 177:99-III.

6. Roger M: Influence of host genes on HIV-I disease progression. Faseb J 1998, I2(9):625-632.

7. Mikhail $M$, Wang $B$, Saksena NK: Mechanisms involved in nonprogressive HIV disease. AIDS Rev 2003, 5(4):230-244.

8. Shioda $T$, Oka S, Xin X, Liu H, Harukuni R, Kurotani A, Fukushima M, Hasan MK, Shiino T, Takebe $Y$, Iwamoto A, Nagai $Y$ : In vivo sequence variability of human immunodeficiency virus type I envelope gp | 20: association of $\mathrm{V} 2$ extension with slow disease progression. J Virol I997, 7 I (7):487| -488I.

9. Wang B, Spira TJ, Owen S, Lal RB, Saksena NK: HIV-I strains from a cohort of American subjects reveal the presence of a V2 region extension unique to slow progressors and non-progressors. Aids 2000, 14(3):213-223

10. Iversen AK, Shpaer EG, Rodrigo AG, Hirsch MS, Walker BD, Sheppard HW, Merigan TC, Mullins Jl: Persistence of attenuated rev genes in a human immunodeficiency virus type I-infected asymptomatic individual. J Virol 1995, 69(9):5743-5753.

II. Alexander L, Aquino-Dejesus MJ, Chan M, Andiman WA: Inhibition of human immunodeficiency virus type I (HIV-I) replication by a two-amino-acid insertion in HIV-I Vif from a nonprogressing mother and child. J Virol 2002, 76(20): 10533-10539.

12. Binley JM, Jin X, Huang Y, Zhang L, Cao Y, Ho DD, Moore JP: Persistent antibody responses but declining cytotoxic T-lymphocyte responses to multiple human immunodeficiency virus type $I$ antigens in a long-term nonprogressing individual with a defective $\mathrm{p} I 7$ proviral sequence and no detectable viral RNA expression. J Virol 1998, 72(4):3472-3474.

13. Wang B, Ge YC, Palasanthiran P, Xiang SH, Ziegler J, Dwyer DE, Randle C, Dowton D, Cunningham A, Saksena NK: Gene defects clustered at the C-terminus of the vpr gene of HIV-I in longterm nonprogressing mother and child pair: in vivo evolution of vpr quasispecies in blood and plasma. Virology 1996, 223(I):224-232.

14. Dean M, Carrington M, Winkler C, Huttley GA, Smith MW, Allikmets R, Goedert JJ, Buchbinder SP, Vittinghoff E, Gomperts E, Donfield S, Vlahov D, Kaslow R, Saah A, Rinaldo C, Detels R, O'Brien S]: Genetic restriction of HIV-I infection and progression to AIDS by a deletion allele of the CKR5 structural gene. Hemophilia Growth and Development Study, Multicenter AIDS Cohort Study, Multicenter Hemophilia Cohort Study, San Francisco City Cohort, ALIVE Study. Science 1996, 273(5283): I856-1862.

15. Eugen-Olsen J, Iversen AK, Garred P, Koppelhus U, Pedersen C, Benfield TL, Sorensen AM, Katzenstein T, Dickmeiss E, Gerstoft J, Skinhoj P, Svejgaard A, Nielsen JO, Hofmann B: Heterozygosity for a deletion in the CKR-5 gene leads to prolonged AIDS-free survival and slower CD4 T-cell decline in a cohort of HIV-seropositive individuals. Aids 1997, I I(3):305-3 I0.

16. Huang Y, Paxton WA, Wolinsky SM, Neumann AU, Zhang L, He T, Kang S, Ceradini D, Jin Z, Yazdanbakhsh K, Kunstman K, Erickson D, Dragon E, Landau NR, Phair J, Ho DD, Koup RA: The role of a mutant CCR5 allele in HIV-I transmission and disease progression. Nat Med 1996, 2(I I): I240-I 243

17. Smith MW, Dean M, Carrington M, Winkler C, Huttley GA, Lomb DA, Goedert IJ, O'Brien TR, Jacobson LP, Kaslow R, Buchbinder S, Vittinghoff E, Vlahov D, Hoots K, Hilgartner MW, O'Brien SJ: Con- trasting genetic influence of CCR2 and CCR5 variants on HIV-I infection and disease progression. Hemophilia Growth and Development Study (HGDS), Multicenter AIDS Cohort Study (MACS), Multicenter Hemophilia Cohort Study (MHCS), San Francisco City Cohort (SFCC), ALIVE Study. Science 1997, 277(5328):959-965.

18. Cullen BR: HIV-I auxiliary proteins: making connections in a dying cell. Cell 1998, 93(5):685-692.

19. Emerman M, Malim MH: HIV-I regulatory/accessory genes: keys to unraveling viral and host cell biology. Science 1998, 280(537I): | 880-| 884

20. Kjems J, Askjaer P: Rev protein and its cellular partners. Adv Pharmacol 2000, 48:25I-298.

21. Pollard VW, Malim MH: The HIV-I Rev protein. Annu Rev Microbiol 1998, 52:49|-532.

22. Madore SJ, Tiley LS, Malim MH, Cullen BR: Sequence requirements for Rev multimerization in vivo. Virology 1994 202(I): $186-194$.

23. Malim MH, Cullen BR: HIV-I structural gene expression requires the binding of multiple Rev monomers to the viral RRE: implications for HIV-I latency. Cell I99I, 65(2):24I-248.

24. Olsen HS, Cochrane AW, Dillon PJ, Nalin CM, Rosen CA: Interaction of the human immunodeficiency virus type I Rev protein with a structured region in env MRNA is dependent on multimer formation mediated through a basic stretch of amino acids. Genes Dev 1990, 4(8): 1357-1364.

25. Zapp ML, Hope TJ, Parslow TG, Green MR: Oligomerization and RNA binding domains of the type I human immunodeficiency virus Rev protein: a dual function for an arginine-rich binding motif. Proc Natl Acad Sci U S A I 99I, 88( I 7):7734-7738.

26. Hua J, Caffrey J], Cullen BR: Functional consequences of natural sequence variation in the activation domain of HIV-I Rev. Virology 1996, 222(2):423-429.

27. Churchill M, Steriovski J, Gray L, Cowley D, Chatfield C, Learmont I, Sullivan JS, Crowe SM, Mills J, Brew BJ, Wesselingh SL, McPhee DA, Gorry PR: Longitudinal analysis of nef/long terminal repeatdeleted HIV-I in blood and cerebrospinal fluid of a long-term survivor who developed HIV-associated dementia. J Infect Dis 2004, 190(I2):2I8I-2186.

28. Geczy AF, Kuipers H, Coolen M, Ashton LJ, Kennedy C, Ng G, Dodd R, Wallace R, Le T, Raynes-Greenow CH, Dyer WB, Learmont JC, Sullivan JS: HLA and other host factors in transfusion-acquired HIV-I infection. Hum Immunol 2000, 6 I(2): I72-176.

29. Bohnlein E, Berger J, Hauber J: Functional mapping of the human immunodeficiency virus type I Rev RNA binding domain: new insights into the domain structure of Rev and Rex. J Virol 1991, 65( I 2):705।-7055.

30. Daly TJ, Cook KS, Gray GS, Maione TE, Rusche JR: Specific binding of HIV-I recombinant Rev protein to the Rev-responsive element in vitro. Nature 1989, 342(625I):816-819.

31. Hope TJ, Huang XJ, McDonald D, Parslow TG: Steroid-receptor fusion of the human immunodeficiency virus type I Rev transactivator: mapping cryptic functions of the argininerich motif. Proceedings of the National Academy of Sciences USA 1990 , 87(19):7787-779|

32. Zapp ML, Green MR: Sequence-specific RNA binding by the HIV-I Rev protein. Nature 1989, 342(6250):714-716.

33. Battiste JL, Mao H, Rao NS, Tan R, Muhandiram DR, Kay LE, Frankel $A D$, Williamson JR: Alpha helix-RNA major groove recognition in an HIV-I rev peptide-RRE RNA complex. Science 1996, 273(528I): |547-|55|.

34. Jensen TH, Jensen A, Szilvay AM, Kjems J: Probing the structure of HIV-I Rev by protein footprinting of multiple monoclonal antibody-binding sites. FEBS Lett 1997, 4I 4(I):50-54.

35. Jensen TH, Leffers $\mathrm{H}$, Kjems J: Intermolecular binding sites of human immunodeficiency virus type I Rev protein determined by protein footprinting. I Biol Chem 1995, 270(23): 13777-13784.

36. Gorry PR, Howard JL, Churchill MJ, Anderson JL, Cunningham A, Adrian D, McPhee DA, Purcell DF: Diminished production of human immunodeficiency virus type $I$ in astrocytes results from inefficient translation of gag, env, and nef mRNAs despite efficient expression of Tat and Rev. Journal of Virology 1999, 73(1):352-361.

37. Churchill MJ, Moore JL, Rosenberg M, Brighty DW: The revresponsive element negatively regulates human immunode- 
ficiency virus type I env mRNA expression in primate cells. J Virol 1996, 70(9):5786-5790.

38. Ruhl M, Himmelspach M, Bahr GM, Hammerschmid F, Jaksche $H$, Wolff B, Aschauer H, Farrington GK, Probst H, Bevec D, et al.: Eukaryotic initiation factor $5 A$ is a cellular target of the human immunodeficiency virus type I Rev activation domain mediating trans-activation. J Cell Biol 1993, I23(6 Pt I): $1309-1320$.

39. Bogerd HP, Fridell RA, Madore S, Cullen BR: Identification of a novel cellular cofactor for the Rev/Rex class of retroviral regulatory proteins. Cell 1995, 82(3):485-494.

40. Fritz CC, Green MR: HIV Rev uses a conserved cellular protein export pathway for the nucleocytoplasmic transport of viral RNAs. Curr Biol 1996, 6(7):848-854.

41. Fritz CC, Zapp ML, Green MR: A human nucleoporin-like protein that specifically interacts with HIV Rev. Nature 1995, 376(6540):530-533.

42. Stutz F, Izaurralde E, Mattaj IW, Rosbash M: A role for nucleoporin FG repeat domains in export of human immunodeficiency virus type I Rev protein and RNA from the nucleus. Mol Cell Biol 1996, I 6( I 2):7144-7I50.

43. Stutz F, Neville M, Rosbash M: Identification of a novel nuclear pore-associated protein as a functional target of the HIV-I Rev protein in yeast. Cell 1995, 82(3):495-506.

44. Fornerod M, Ohno M, Yoshida M, Mattaj IW: CRMI is an export receptor for leucine-rich nuclear export signals. Cell 1997, 90(6): $105 \mid-1060$.

45. Fukuda M, Asano S, Nakamura T, Adachi M, Yoshida M, Yanagida M, Nishida E: CRMI is responsible for intracellular transport mediated by the nuclear export signal. Nature 1997, 390(6657):308-3।I.

46. Neville M, Stutz F, Lee L, Davis LI, Rosbash M: The importin-beta family member Crm Ip bridges the interaction between Rev and the nuclear pore complex during nuclear export. Curr Bio 1997, 7(10):767-775.

47. Askjaer $P$, Kjems J: Mapping of multiple RNA binding sites of human T-cell lymphotropic virus type I rex protein within 5'and 3'-Rex response elements. I Biol Chem 1998, 273(19): I|463-I|47|.

48. Kreutz R, Dietrich U, Kuhnel H, Nieselt-Struwe K, Eigen M, Rubsamen-Waigmann $\mathrm{H}$ : Analysis of the envelope region of the highly divergent HIV-2ALT isolate extends the known range of variability within the primate immunodeficiency viruses. AIDS Res Hum Retroviruses 1992, 8(9):1619-1629.

49. Liitsola K, Holm K, Bobkov A, Pokrovsky V, Smolskaya T, Leinikki P, Osmanov S, Salminen M: An AB recombinant and its parenta HIV type I strains in the area of the former Soviet Union: low requirements for sequence identity in recombination. UNAIDS Virus Isolation Network. AIDS Res Hum Retroviruses 2000, I 6( I I): 1047-1053.

50. Willey RL, Rutledge RA, Dias S, Folks T, Theodore T, Buckler CE, Martin MA: Identification of conserved and divergent domains within the envelope gene of the acquired immunodeficiency syndrome retrovirus. Proc Natl Acad Sci U S A 1986, 83(14):5038-5042.

5I. Collman R, Balliet JW, Gregory SA, Friedman H, Kolson DL, Nathanson N, Srinivasan A: An infectious molecular clone of an unusual macrophage-tropic and highly cytopathic strain of human immunodeficiency virus type I. Journal of Virology 1992, 66(I2):75|7-752I.

52. Bernardin F, Herring BL, Peddada L, Delwart EL: Primary infection of a male plasma donor with divergent HIV variants from the same source followed by rapid fluctuations in their relative frequency and viral recombination. AIDS Res Hum Retroviruses 2003, I (I I): 1009-1015.

53. Bernardin F, Kong D, Peddada L, Baxter-Lowe LA, Delwart E: Human immunodeficiency virus mutations during the first month of infection are preferentially found in known cytotoxic T-lymphocyte epitopes. J Virol 2005, 79 (1 7): I I523-I I528. 